\title{
PENGARUH TEMPERATUR PEREBUSAN JERAMI TERHADAP SIFAT FISIS MEKANIS PAPAN PARTIKEL
}

\author{
M. I. Iskandar \\ Pusat Penelitian dan Pengembangan Hasil Hutan \\ Jl. Gunung Batu No. 5, Bogor \\ e-mail: mi.iskandar53@gmail.com
}

\author{
ABSTRACT \\ Effect of Temperature of Straw Boiling on Mechanical and Physical Properties \\ of Particle Board
}

\begin{abstract}
Levels of extractive substances in the straw as much as $10-15 \%$ and $12-18 \%$ silica content respectively. Two of these substances can inhibit good adhesion bonding between the particles during the sealing process. Treatment of straw boiling before gluing process can reduce the negative effects of extractive substances to the bonding adhesive. The purpose of this study was to determine the effect of temperature of the boiling straw on mechanical and physical properties of particle board. The tested physical properties included density, moisture content, thickness swelling and water absorption while the mechanical properties tested included flexural modulus, fracture modulus, internal bonding strength and screw holding strength. Analysisof statistic of the data used was Complete Random Design $(R A L)$. The treatment consisted of a five-level with three replications so that the total number of trials was fifteen. To determine the effect of treatment carried out the Analysis of Variance. To determine the effect of treatment was significantly different would do a further test the Duncan's multiple range test. Processing data using SAS software, version 6123. The results showed an increase in the temperature of straw boiling was very significant and fluctuative on the properties of particle board and the moisture content, thickness swelling 24 hours, flexural modulus (MOE), fracture modulus (MOR), but did not significant affect the density and internal bonding strength. Boiling temperature $40^{\circ} \mathrm{C}$ on straw produce panels with the best qualities. The properties of particle board research results that met the requirements of Standard JIS A 5908: 215 only the density and moisture content.
\end{abstract}

Keywords: temperature, boiling, straw, mechanical physical properties

\begin{abstract}
ABSTRAK
Kadar zat ekstraktif dalam jerami sebanyak $10-15 \%$ dan kadar silika 12-18\%. Dua zat tersebut dapat menghambat ikatan rekat yang baik antar partikel pada waktu proses perekatan. Perlakuan perebusan jerami sebelum proses perekatan dapat mengurangi pengaruh negatif zat ekstraktif terhadap ikatan rekat. Tujuan penelitian ini adalah untuk mengetahui pengaruh temperatur perebusan jerami terhadap sifat fisis mekanis papan partikel. Sifat fisis yang diuji meliputi kerapatan, kadar air, pengembangan tebal dan daya serap air sedangkan sifat mekanis yang diuji meliputi modulus lentur, modulus patah, keteguhan rekat internal dan kuat pegang sekrup. Analisis statistik data yang digunakan adalah Rancangan Acak Lengkap (RAL). Perlakuan terdiri dari lima taraf dengan ulangan sebanyak tiga sehingga jumlah total percobaan adalah lima belas. Untuk mengetahui pengaruh dari perlakuan dilakukan analisis ragam (Analysis of Variance). Untuk mengetahui pengaruh berbeda nyata perlakuan dilakukan uji lanjut dengan uji wilayah berganda Duncan. Pengolahan data menggunakan software SAS versi 6.123. Hasil penelitian menunjukkan peningkatan temperatur perebusan jerami berpengaruh sangat nyata dan fluktuatif terhadap sifat-sifat papan partikel dan kadar air, pengembangan tebal 24 jam, modulus lentur (MOE), modulus patah (MOR), tetapi tidak berpengaruh nyata terhadap kerapatan dan keteguhan rekat internal. Perebusan jerami pada suhu $40^{\circ} \mathrm{C}$ menghasilkan panil dengan sifat-sifat terbaik. Sifat-sifat papan partikel hasil penelitian yang memenuhi persyaratan Standar JIS A 5908:215 hanya kerapatan dan kadar air.
\end{abstract}

Kata kunci: temperatur, perebusan, jerami, sifat fisis dan mekanis

\section{PENDAHULUAN}

Papan partikel adalah salah satu jenis produk komposit yang terbuat dari partikelpartikel kayu atau bahan-bahan berlignoselulosa lainnya yang diikat dengan perekat sintetis atau bahan pengikat lain kemudian dikempa panas (Maloney 1993). Bahan berlignoselulosa dapat berupa kayu dan limbah pertanian seperti: ampas tebu, jerami, batang kelapa sawit, tandan kosong kelapa sawit, sekam padi, sabut kelapa dan lainlain. 
Jerami padi merupakan salah satu jenis limbah pertanian yang potensial dapat digunakan sebagai bahan baku dalam produksi papan partikel. Namun menurut Skinner et al. (1999), jerami memiliki kandungan zat ekstraktif dan silika yang lebih besar dari kayu khususnya kayu softwood. Kadar zat ekstraktif antara lain 10-15\% dan kadar silika antara $12-18 \%$. Dua hal tersebut merupakan kelemahan dari jerami sebagai bahan baku pembuatan papan partikel karena mempengaruhi sifat-sifat papan partikel yang akan dibuat. Zat ekstraktif dapat menghambat penetrasi perekat pada proses perekatan. Sedangkan silika menimbulkan abrasif terhadap mata pisau alat produksi. Selain itu, silika menyebabkan lemahnya ikatan antar partikel dengan perekat, dan antara partikel dengan partikel yang lainnya.

Beberapa perlakuan pendahuluan yang dapat dilakukan untuk mengurangi pengaruh zat ekstraktif dan silika amorphous terhadap ikatan rekat antar partikel adalah dengan perlakuan perendaman panas yang bertujuan untuk melarutkan zat-zat ekstraktif seperti gula, pati, zat warna dan sebagainya. Menurut Trisyulianti (1996), perendaman tandan kosong kelapa sawit dalam air panas pada suhu $100^{\circ} \mathrm{C}$ selama 24 jam menghasilkan nilai keteguhan papan partikel $(95.25$ $\mathrm{kg} / \mathrm{cm}^{2}$ ) yang lebih baik bila dibandingkan dengan papan partikel yang partikelnya direndam air pada suhu kamar selama 24 jam $\left(61.00 \mathrm{~kg} / \mathrm{cm}^{2}\right)$. Menurut Saputra (2004), perebusan partikel tandan kosong kelapa sawit pada suhu $80 \pm 3^{\circ} \mathrm{C}$ menghasilkan sifatsifat papan partikel yang tidak berbeda nyata dengan perlakuan perendaman partikel dengan suhu $70 \pm 3^{\circ} \mathrm{C}$. Namun menurut Hadi (2008), perendaman panas $\left(80 \pm 3^{\circ} \mathrm{C}\right)$ partikel kayu meranti sangat berpengaruh positif terhadap stabilitas dimensi papan partikel. Tujuan dari penelitian ini adalah untuk mengetahui pengaruh temperatur perebusan jerami terhadap sifat fisis mekanis papan partikel.

\section{BAHAN DAN METODE}

\section{Bahan}

Bahan yang digunakan dalam penelitian ini yaitu batang jerami, perekat urea formaldehida cair, parafin cair,. Batang jerami diperoleh dari daerah Bogor Industry.

\section{Metode}

Metode yang dilakukan dalam penelitian ini adalah sebagai berikut:

1. Persiapan bahan baku jerami dalam kondisi segar dan baru dipanen.

2. Pembuatan partikel jerami dengan panjang 3-5 $\mathrm{mm}$, lebar 1-2 $\mathrm{mm}$ dan tebal 0,25-0,40 $\mathrm{mm}$.

3. Pemisahan partikel (penyaringan).

4. Perebusan partikel.

Partikel jerami diberi perlakuan yaitu perebusan dalam air panas dan tanpa perebusan (control). Ada lima jenis perlakuan, yaitu:

a. Perebusan partikel dalam air panas pada suhu $40^{\circ} \mathrm{C} \pm 3^{\circ} \mathrm{C}$ selama 2 jam

b. Perebusan partikel dalam air panas pada suhu $60^{\circ} \mathrm{C} \pm 3^{0} \mathrm{C}$ selama 2 jam

c. Perebusan partikel dalam air panas pada suhu $80^{\circ} \mathrm{C} \pm 3^{\circ} \mathrm{C}$ selama 2 jam

d. Perebusan partikel dalam air panas pada suhu $100^{\circ} \mathrm{C} \pm 3^{0} \mathrm{C}$ selama 2 jam

e. Tanpa perebusan partikel

5. Pengeringan partikel.

6. Persiapan perekat.

7. Pencampuran perekat dengan partikel (blending).

8. Pembentukan lapik (lembaran).

9. Pengempaan panas.

10. Pengkondisian.

11. Pembuatan contoh uji mengikuti standar Jepang (JIS A 5098-2015).

12. Analisis data menggunakan rancangan percobaan acak lengkap dengan tiga ulangan. Banyaknya perlakuan adalah limaperlakuan berdasarkan suhu perebusan dan control (tanpa perebusan partikel).

\section{HASIL DAN PEMBAHASAN}

\section{Kerapatan}

Data pengujian kerapatan tercantum pada Gambar 1. Dari Gambar 1 terlihat bahwa nilai kerapatan papan partikel ada diantara $0.63 \mathrm{~g} / \mathrm{cm}^{3}-0.68 \mathrm{~g} / \mathrm{cm}^{3}$. Untuk mengetahui pengaruh perlakuan terhadap kerapatan dilakukan uji sidik ragam 
disajikan pada Tabel 1. Sidik ragam menunjukkan bahwa nilai $\mathrm{F}_{\text {hitung }} \leq \mathrm{F}_{0.05}$ sehingga diketahui bahwa perlakuan perebusan partikel jerami tidak berpengaruh nyata terhadap kerapatan papan partikel pada taraf nyata $5 \%$.

\section{Kadar Air}

Data pengujian kadar air papan partikel disajikan pada Gambar 2. Untuk mengetahui pengaruh perlakuan suhu perebusan terhadap kadar air dilakukan uji sidik ragam disajikan pada Tabel 2. Sidik ragam

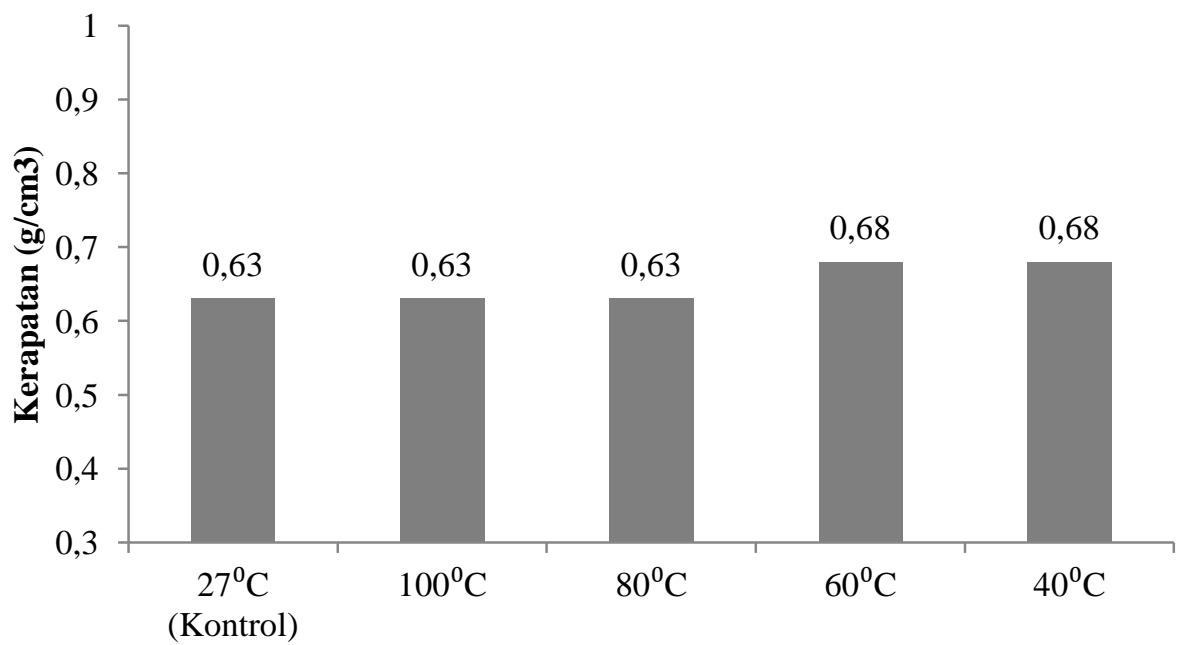

Perlakuan Perebusan menunjukkan bahwa $\mathrm{F}_{\text {hitung }}>\mathrm{F}_{0.01}$ sehingga dapat diketahui bahwa perlakuan perebusan partikel berpengaruh sangat nyata terhadap kadar air papan partikel pada taraf $1 \%$.

Untuk mengetahui perbedaan nyata perlakuan terhadap kadar air dilakukan uji Duncan yang disajikan pada Tabel 3. Uji Duncan menunjukkan bahwa perlakuan perebusan partikel pada suhu $60^{\circ} \mathrm{C}, 80^{\circ} \mathrm{C}$ dan $100^{\circ} \mathrm{C}$ tidak menghasilkan kadar air yang berbeda, tetapi berbeda dengan suhu perebusan $40^{\circ} \mathrm{C}$.

Gambar 1. Nilai Rata-rata Kerapatan Papan Partikel

Tabel 1. Sidik Ragam Kerapatan Papan Partikel

\begin{tabular}{ccccccc}
\hline $\begin{array}{c}\text { Sumber } \\
\text { Keragaman }\end{array}$ & $\begin{array}{c}\text { Derajat } \\
\text { Bebas }\end{array}$ & $\begin{array}{c}\text { Jumlah } \\
\text { Kuadrat }\end{array}$ & $\begin{array}{c}\text { Kuadrat } \\
\text { Tengah }\end{array}$ & F-hitung & \multicolumn{2}{c}{ F tabel } \\
\cline { 6 - 7 } Perlakuan & 4 & 0.00 & 0.00 & $3.32^{\text {tn }}$ & 0.05 & 0.01 \\
Galat & 10 & 0.00 & 0.00 & - & - & 5.99 \\
Total & 14 & 0.01 & - & - & - & - \\
\hline
\end{tabular}

Keterangan: $\mathrm{tn}=$ tidak nyata

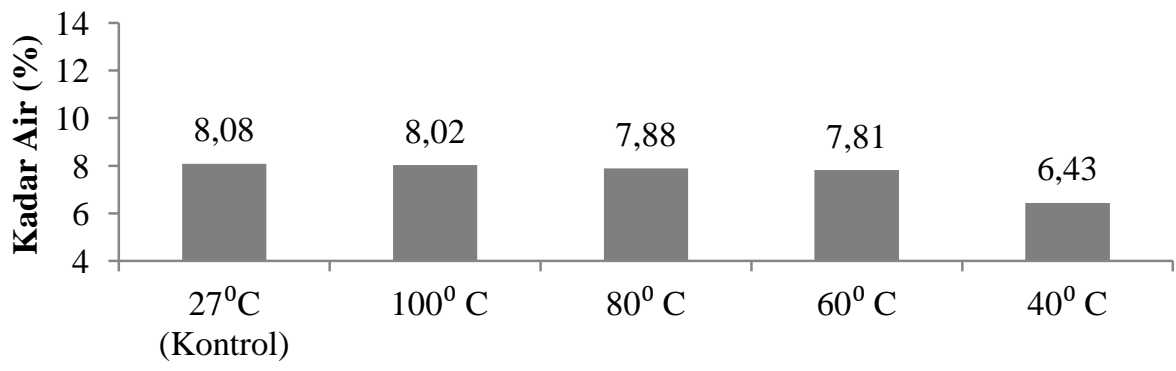

Perlakuan Perebusan

Gambar 2. Nilai Rata-rata Kadar Air Papan Partikel 


\section{Pengembangan Tebal}

Data hasil pengujian pengembangan tebal papan partikel setelah perendaman selama 24 jam dalam air disajikan pada Gambar 3.
Dari Gambar 3 dapat dilihat bahwa nilai pengembangan tebal semakin meningkat dengan naiknya suhu perebusan. Untuk mengetahui pengaruh perlakuan suhu perebusan terhadap pengembangan tebal dilakukan uji ragam disajikan pada Tabel 4.

Tabel 2. Sidik Ragam Kadar Air Papan Partikel

\begin{tabular}{ccccccc}
\hline $\begin{array}{c}\text { Sumber } \\
\text { Keragaman }\end{array}$ & $\begin{array}{c}\text { Derajat } \\
\text { Bebas }\end{array}$ & $\begin{array}{c}\text { Jumlah } \\
\text { Kuadrat }\end{array}$ & $\begin{array}{c}\text { Kuadrat } \\
\text { Tengah }\end{array}$ & F-hitung & \multicolumn{2}{c}{ F tabel } \\
\hline Perlakuan & 4 & 5.69 & 1.42 & $6.66^{\text {sn }}$ & 3.48 & 0.05 \\
Galat & 10 & 2.14 & 0.21 & - & - & - \\
Total & 14 & 7.83 & - & - & - & - \\
\hline
\end{tabular}

Keterangan: $s n=$ sangat nyata

Tabel 3. Uji Duncan Kadar Air Papan Partikel

\begin{tabular}{cccc}
\hline No. & Perlakuan perebusan & Nilai rata-rata Kadar Air (\%) & Hasil uji Duncan \\
\hline 1 & Kontrol (Tanpa Perebusan) & 8.08 & $\mathrm{~A}$ \\
2 & Suhu $100^{\circ} \mathrm{C}$ & 8.02 & $\mathrm{~A}$ \\
3 & Suhu $80^{\circ} \mathrm{C}$ & 7.88 & $\mathrm{~A}$ \\
4 & Suhu $60^{\circ} \mathrm{C}$ & 7.81 & $\mathrm{~A}$ \\
5 & Suhu $40^{\circ} \mathrm{C}$ & 6.43 & $\mathrm{~B}$ \\
\hline
\end{tabular}

Keterangan: huruf yang sama pada kolom hasil uji Duncan menunjukkan nilai yang tidak berbeda nyata pada taraf $5 \%$

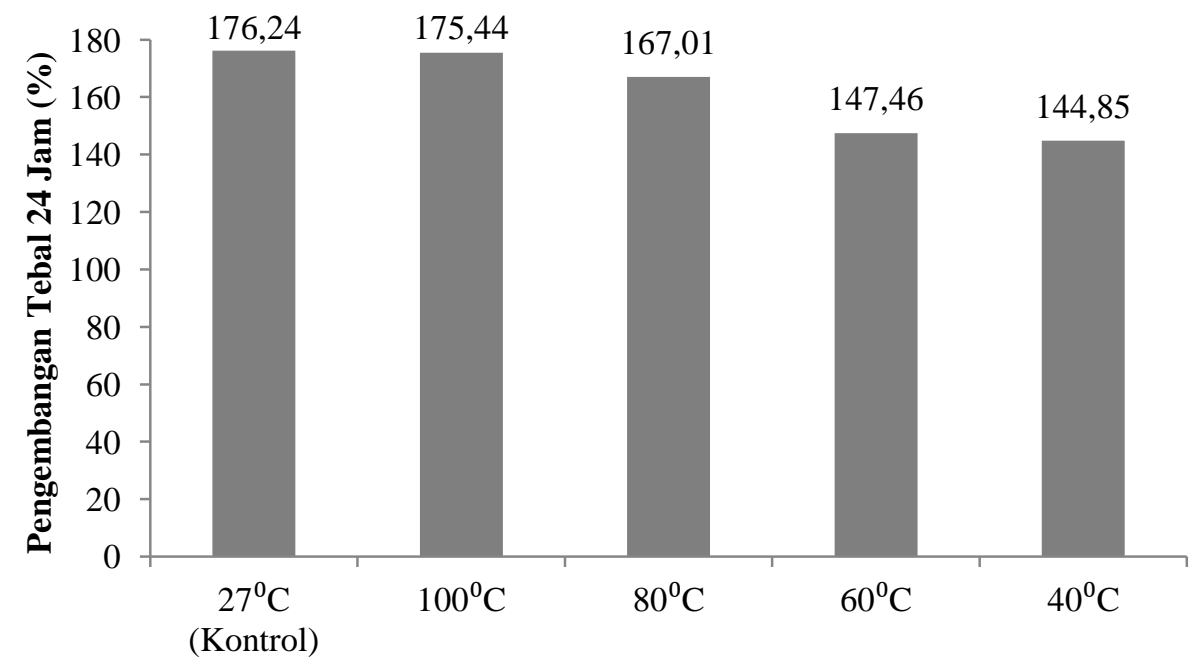

Perlakuan Perebusan

Gambar 3. Nilai Rata-rata Pengembangan Tebal Papan Partikel

Tabel 4. Sidik Ragam Pengembangan Tebal 24 jam Papan Partikel Setelah Perendaman dalam Air 24 Jam

\begin{tabular}{ccccccc}
\hline Sumber & Derajat & Jumlah & Kuadrat & F-hitung & \multicolumn{2}{c}{ F tabel } \\
\cline { 6 - 7 } Keragaman & Bebas & Kuadrat & Tengah & & 0.05 & 0.01 \\
\hline Perlakuan & 4 & 2742.51 & 685.63 & $10.84^{\mathrm{sn}}$ & 3.48 & 5.99 \\
Galat & 10 & 632.35 & 63.23 & - & - & - \\
Total & 14 & 3374.86 & - & - & - & - \\
\hline
\end{tabular}

Keterangan: sn= sangat nyata 
Tabel 5. Uji Duncan Pengembangan Tebal Papan Partikel Setelah Perendaman dalam Air Selama 24 Jam

\begin{tabular}{cccc}
\hline No. & Perlakuan perebusan & $\begin{array}{c}\text { Nilai rata-rata Pengembangan } \\
\text { Tebal }(\%)\end{array}$ & Hasil uji Duncan \\
\hline 1 & Kontrol (Tanpa Perebusan) & 176.24 & $\mathrm{~A}$ \\
2 & Suhu $100^{\circ} \mathrm{C}$ & 175.44 & $\mathrm{~A}$ \\
3 & Suhu $80^{\circ} \mathrm{C}$ & 167.01 & $\mathrm{~A}$ \\
4 & Suhu $60^{\circ} \mathrm{C}$ & 147.46 & $\mathrm{~B}$ \\
5 & Suhu $40^{\circ} \mathrm{C}$ & 144.85 & $\mathrm{~B}$ \\
\hline
\end{tabular}

Keterangan: huruf yang sama pada kolom hasil uji Duncan menunjukkan nilai yang tidak berbeda nyata pada taraf $5 \%$

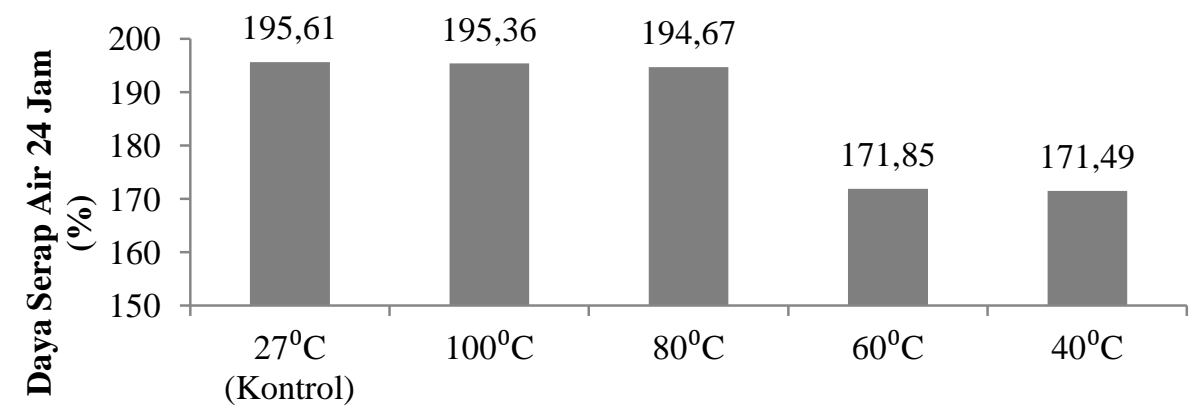

Perlakuan Perebusan

Gambar 4. Nilai Rata-rata Daya Serap Air 24 Jam Papan Partikel

Sidik ragam menunjukkan bahwa nilai $\mathrm{F}_{\text {hitung }}>\mathrm{F}_{0.01}$ sehingga dapat diketahui bahwaa perlakuan suhu perebusan partikel jerami berpengaruh sangat nyata terhadap pengembangan tebal papan partikel pada taraf nyata $1 \%$.

Untuk mengetahui perbedaan nyata suhu perebusan terhadap pegembangan tebal dilakukan uji Duncan yang disajikan pada Tabel 5.

Hasil uji Duncan menunjukkan bahwa perebusan partikel pada suhu $80^{\circ} \mathrm{C}, 100^{\circ} \mathrm{C}$ dan kontrol tidak berbeda nyata, akan tetapi berbeda dengan suhu perebusan $40^{\circ} \mathrm{C}$ dan $60^{\circ} \mathrm{C}$. Papan partikel dengan suhu perebusan $40^{\circ} \mathrm{C}$ menghasilkan nilai yang optimal terhadap respon pengembangan tebal.

\section{Daya Serap Air}

Data pengujian daya serap air papan partikel setelah perendaman dalam 24 jam disajikan pada Gambar 4.

Dari Gambar 4 dapat dilihat bahwa nilai daya serap air semakin meningkat dengan naiknya suhu perebusan partikel. Untuk mengetahui pengaruh perlakuan suhu perebusan terhadap daya serap air dilakukan uji sidik ragam yang disajikan pada Tabel 6 .

Sidik ragam menunjukkan bahwa nilai $\mathrm{F}_{\text {hitung }}>\mathrm{F}_{0.01}$ sehingga diketahui bahwa perlakuan suhu perebusan partikel jerami berpengaruh sangat nyata terhadap daya serap air pada taraf $1 \%$. Untuk mengetahui perbedaan nyata perlakuan terhadap daya serap air dilakukan uji Duncan yang disajikan pada Tabel 7.

Hasil uji Duncan menunjukkan bahwa perlakuan perebusan partikel pada suhu $80^{\circ} \mathrm{C}, 100^{\circ} \mathrm{C}$ dan kontrol tidak berbeda nyata akan tetapi berbeda nyata terhadap nilai pengembangan tebal yang partikelnya direbus pada suhu $40^{\circ} \mathrm{C}$ dan $60^{\circ} \mathrm{C}$. perlakuan suhu perebusan $40^{\circ} \mathrm{C}$ menghasilkan nilai yang optimal terhadap respon daya serap air (171.49\%).

\section{Modulus Lentur (Modulus of Elasticity $=$ MOE) \\ Data pengujian modulus lentur (MOE)} papan partikel disajikan pada Gambar 5. Dari Gambar 5 dapat dilihat bahwa nilai modulus lentur berfluktuasi seiring dengan kenaikan suhu perebusan partikel. Nilai 
modulus lentur terendah $\left(4.05 \times 10^{3} \mathrm{~kg} / \mathrm{cm}^{2}\right)$ diperoleh papan partikel tanpa perebusan. Sedangkan nilai modulus lentur tertinggi $\left(9.38 \times 10^{3} \mathrm{~kg} / \mathrm{cm}^{2}\right)$ diperoleh papan partikel dengan perlakuan perebusan pada suhu $40^{\circ} \mathrm{C}$. untuk mengetahui pengaruh perlakuan suhu perebusan terhadap modulus lentur dilakukan uji sidik ragam yang disajikan pada Tabel 8.

Sidik ragam menunjukkan bahwa nilai $\mathrm{F}_{\text {hitung }}>\mathrm{F}_{0.01}$ sehingga diketahui bahwa perlakuan suhu perebusan partikel berpengaruh sangat nyata terhadap modulus lentur papan partikel pada taraf nyata $1 \%$. Selanjutnya untuk mengetahui sejauh mana perlakuan suhu perebusan memberi perbedaan nyata terhadap modulus lentur dilakukan uji Duncan yang disajikan pada Tabel 9.
Hasil uji Duncan menunjukkan bahwa perlakuan perebusan pada suhu $60^{\circ} \mathrm{C}, 80^{\circ} \mathrm{C}$ dan $100^{\circ} \mathrm{C}$ tidak berbeda nyata, akan tetapi berbeda nyata dengan suhu $40^{\circ} \mathrm{C}$. nilai modulus lentur kontrol berbeda nyata dengan suhu $40^{\circ} \mathrm{C}$ dan $100^{\circ} \mathrm{C}$, tetapi tidak berbeda nyata dengan suhu perebusan partikel $60^{\circ} \mathrm{C}$ dan $80^{\circ} \mathrm{C}$.

\section{Modulus Patah (Modulus of Rupture = MOR)}

Data pengujian keteguhan patah (MOR) papan partikel disajikan pada Gambar 6 .

Dari Gambar 6 dapat dilihat bahwa peningkatan suhu perebusan partikel berfluktuasi terhadap nilai modulus patah. Untuk mengetahui pengaruh perlakuan suhu perebusan terhadap modulus patah dilakukan uji sidik ragam yang disajikan pada Tabel 10.

Tabel 6. Sidik Ragam Daya Serap Air Papan Partikel Setelah Perendaman Air Selama 24 Jam

\begin{tabular}{ccccccc}
\hline Sumber & Derajat & Jumlah & Kuadrat & F-hitung & \multicolumn{2}{c}{ F tabel } \\
\cline { 6 - 7 } Keragaman & Bebas & Kuadrat & Tengah & & 0.05 & 0.01 \\
\hline Perlakuan & 4 & 1996.94 & 499.24 & $8.600^{\mathrm{sn}}$ & 3.48 & 5.99 \\
Galat & 10 & 580.46 & 58.05 & - & - & - \\
Total & 14 & 2577.41 & - & - & - & - \\
\hline
\end{tabular}

Keterangan: sn= sangat nyata

Tabel 7. Uji Duncan Daya Serap Air Papan Partikel Setelah Perendaman 24 Jam

\begin{tabular}{cccc}
\hline No. & Perlakuan perebusan & $\begin{array}{c}\text { Nilai rata-rata Daya Serap Air } \\
24 \text { jam }(\%)\end{array}$ & Hasil uji Duncan \\
\hline 1 & Kontrol (Tanpa Perebusan) & 195.61 & $\mathrm{~A}$ \\
2 & Suhu $100^{\circ} \mathrm{C}$ & 195.36 & $\mathrm{~A}$ \\
3 & Suhu $80^{\circ} \mathrm{C}$ & 194.67 & $\mathrm{~A}$ \\
4 & Suhu $60^{\circ} \mathrm{C}$ & 171.85 & $\mathrm{~B}$ \\
5 & Suhu $40^{\circ} \mathrm{C}$ & 171.49 & $\mathrm{~B}$ \\
\hline
\end{tabular}

Keterangan: huruf yang sama pada kolom hasil uji Duncan menunjukkan nilai yang tidak berbeda nyata pada taraf $5 \%$

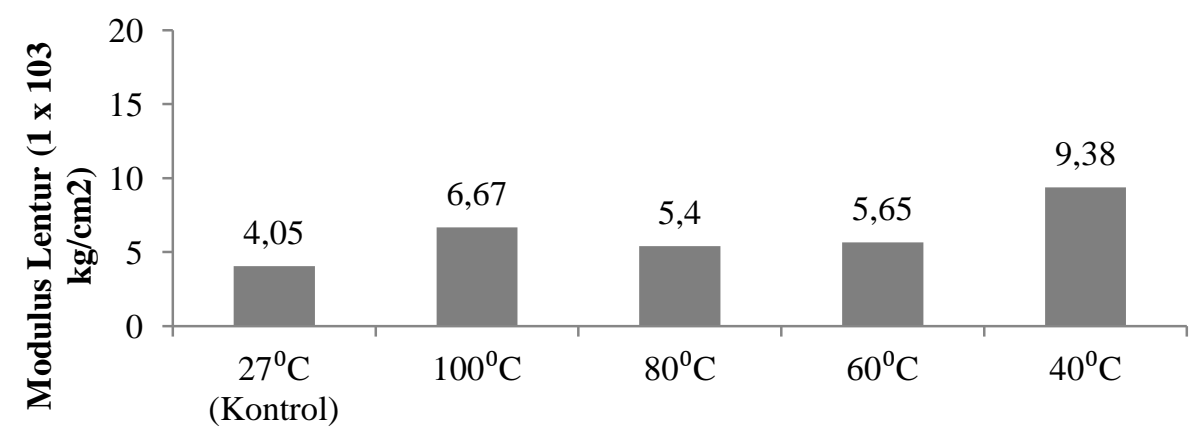

Perlakuan Perebusan

Gambar 5. Nilai Rata-rata Modulus Lentur (MOE) Papan Partikel 
Sidik ragam menunjukkan bahwa nila $\mathrm{F}_{\text {hitung }}>\mathrm{F}_{0.01}$ sehingga diketahui bahwa perlakuan suhu perebusan partikel jerami berpengaruh sangat nyata terhadap keteguhan patah papan partikel jerami pada taraf nyata $1 \%$. Selanjutnya untuk mengetahui perbedaan nyata perlakuan terhadap modulus patah dilakukan uji Duncan yang disajikan pada Tabel 11 .
Hasil uji wilayah berganda Duncan menunjukkan bahwa perlakuan suhu perebusan $80^{\circ} \mathrm{C}$ dan control tidak berbeda nyata, akan tetapi berbeda nyata dengan perebusan partikel pada suhu $40^{\circ} \mathrm{C}, 60^{\circ} \mathrm{C}$ dan $100^{\circ} \mathrm{C}$. perlakuan perebusan suhu $40^{\circ} \mathrm{C}$, $60^{\circ} \mathrm{C}$ dan $100^{\circ} \mathrm{C}$ masing-masing berbeda nyata satu dengan yang lainnya.

Tabel 8. Sidik Ragam Modulus Lentur Papan Partikel

\begin{tabular}{cccccrc}
\hline Sumber & Derajat & Jumlah & Kuadrat & F-hitung & \multicolumn{2}{c}{ F tabel } \\
\cline { 6 - 7 } Keragaman & Bebas & Kuadrat & Tengah & & 0.05 & 0.01 \\
\hline Perlakuan & 4 & 47743587.83 & 11935896.96 & $10.44^{\text {sn }}$ & 3.48 & 5.99 \\
Galat & 10 & 11435582.68 & 1143558.27 & - & - & - \\
Total & 14 & 59179170.51 & - & - & - & - \\
\hline
\end{tabular}

Keterangan: $s n=$ sangat nyata

Tabel 9. Uji Duncan Modulus Lentur Papan Partikel

\begin{tabular}{cccc}
\hline No. & Perlakuan perebusan & $\begin{array}{c}\text { Nilai rata-rata Daya Serap Air } \\
24 \text { jam }(\%)\end{array}$ & Hasil uji Duncan \\
\hline 1 & & 9382.10 & $\mathrm{~A}$ \\
2 & Suhu $40^{\circ} \mathrm{C}$ & 6670.30 & $\mathrm{~B}$ \\
3 & Suhu $100^{\circ} \mathrm{C}$ & 5650.10 & $\mathrm{BC}$ \\
4 & Suhu $80^{\circ} \mathrm{C}$ & 5400.30 & $\mathrm{BC}$ \\
5 & Suhu $60^{\circ} \mathrm{C}$ & 4048.30 & $\mathrm{C}$ \\
\hline
\end{tabular}

Keterangan: huruf yang sama pada kolom hasil uji Duncan menunjukkan nilai yang tidak berbeda nyata pada taraf $5 \%$

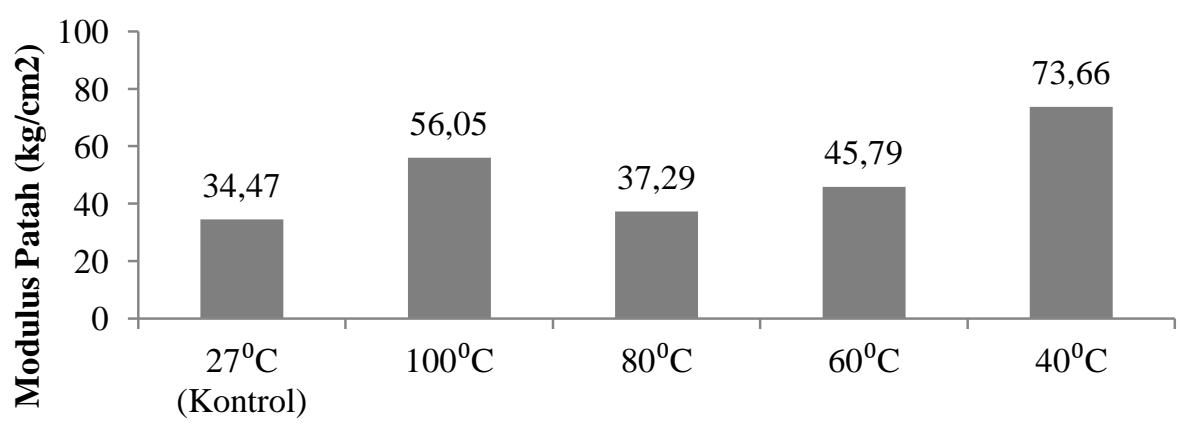

Perlakuan Perebusan

Gambar 6. Nilai Rata-rata Modulus Patah (MOR) Papan Partikel

Tabel 10. Sidik Ragam Modulus Patah Papan Partikel

\begin{tabular}{ccccccc}
\hline Sumber & Derajat & Jumlah & Kuadrat & F-hitung & \multicolumn{2}{c}{ F tabel } \\
\cline { 6 - 8 } Keragaman & Bebas & Kuadrat & Tengah & & 0.05 & 0.01 \\
\hline Perlakuan & 4 & 3045.55 & 761.38 & $52.15^{\mathrm{sn}}$ & 3.48 & 5.99 \\
Galat & 10 & 145.98 & 14.60 & - & - & - \\
Total & 14 & 3191.54 & - & - & - & - \\
\hline
\end{tabular}

Keterangan: sn= sangat nyata 
Tabel 11. Uji Duncan Modulus Patah Papan Partikel

\begin{tabular}{cccc}
\hline No. & Perlakuan perebusan & $\begin{array}{c}\text { Nilai rata-rata Daya Serap Air } \\
24 \text { jam }(\%)\end{array}$ & Hasil uji Duncan \\
\hline 1 & Suhu $40^{\circ} \mathrm{C}$ & 73.66 & $\mathrm{~A}$ \\
2 & Suhu $100^{\circ} \mathrm{C}$ & 56.05 & $\mathrm{~B}$ \\
3 & Suhu $80^{\circ} \mathrm{C}$ & 45.79 & $\mathrm{C}$ \\
4 & Suhu $60^{\circ} \mathrm{C}$ & 37.29 & $\mathrm{D}$ \\
5 & Kontrol (Tanpa Perebusan) & 34.47 & $\mathrm{D}$ \\
\hline
\end{tabular}

Keterangan: huruf yang sama pada kolom hasil uji Duncan menunjukkan nilai yang tidak berbeda nyata pada taraf $5 \%$

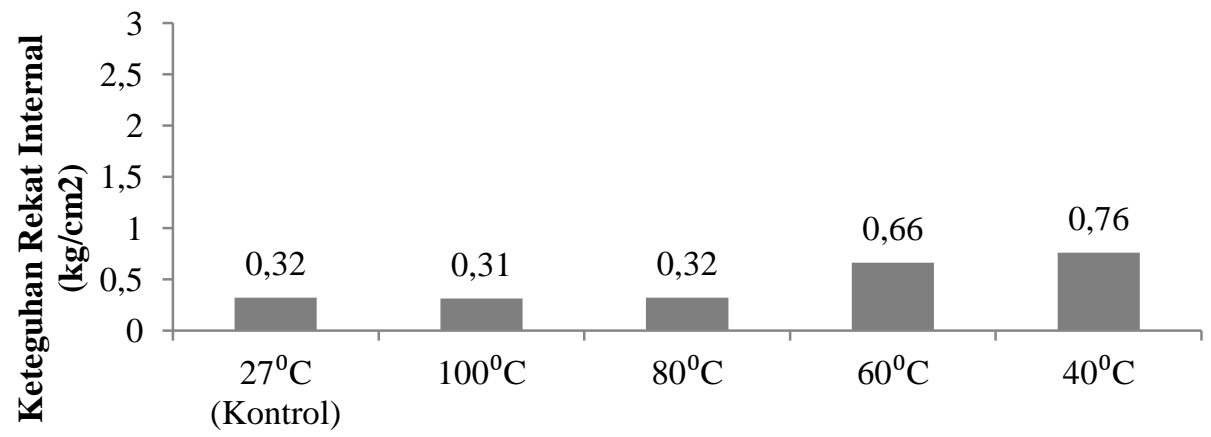

Perlakuan Perebusan

Gambar 7. Nilai Rata-rata Keteguhan Rekat Internal Papan Partikel

Tabel 12 Sidik Ragam Keteguhan Rekat Internal Papan Partikel

\begin{tabular}{ccccccc}
\hline $\begin{array}{c}\text { Sumber } \\
\text { Keragaman }\end{array}$ & $\begin{array}{c}\text { Derajat } \\
\text { Bebas }\end{array}$ & $\begin{array}{c}\text { Jumlah } \\
\text { Kuadrat }\end{array}$ & $\begin{array}{c}\text { Kuadrat } \\
\text { Tengah }\end{array}$ & F-hitung & \multicolumn{2}{c}{ F tabel } \\
\hline Perlakuan & 4 & 0.56 & 0.14 & $1.84^{\text {tn }}$ & 3.05 & 0.01 \\
Galat & 10 & 0.76 & 0.07 & - & - & - \\
Total & 14 & 1.33 & - & - & - & - \\
\hline
\end{tabular}

Keterangan: $\mathrm{tn}=$ tidak nyata

\section{Keteguhan Rekat (Internal Bond $=$ IB)}

Data hasil pengujian keteguhan rekat internal (IB) papan partikel disajikan pada Gambar 7. Dari Gambar 7 dapat dilihat bahwa nilai keteguhan rekat internal semakin rendah seiring meningkatnya suhu perebusan partikel. Untuk mengetahui pengaruh perlakuan suhu perebusan terhadap keteguhan rekat internal dilakukan uji sidik ragam yang disajikan pada Tabel 12.

Hasil analisis ragam menunjukkan bahwa nilai $\mathrm{F}_{\text {hitung }} \leq \mathrm{F}_{0.05}$ sehingga diketahui bahwa perlakuan perebusan partikel jerami tidak berpengaruh nyata terhadap keteguhan rekat internal pada taraf nyata $5 \%$. Standar JIS A 5908-2015 mensyaratkan nilai IB sebesar $1.5 \mathrm{~kg} / \mathrm{cm}^{2}$, sehingga nilai keteguhan rekat internal papan partikel jerami hasil penelitian tidak ada yang memenuhi persyaratan tersebut. Sifa5t keteguhan rekat internal akan sempurna dengan semakin banyaknya perekat dalam pembuatan papan partikel (Haygreen dan Bowyer 1996).

\section{KESIMPULAN}

1. Peningkatan suhu perebusan partikel berpengaruh sangat nyata dan fluktuatif terhadap sifat-sifat papan partikel seperti kadar air, pengembangan tebal 24 jam, daya serap 24 jam, modulus lentur (MOE) dan modulus patah (MOR), tetapi tidak berpengaruh nyata terhadap sifat kerapatan dan keteguhan rekat internal. 
2. Perlakuan perebusan partikel-partikel pada suhu $40^{\circ} \mathrm{C}$ menghasilkan panil dengan sifat-sifat terbaik.

3. Sifat-sifat panel hasil penelitian yang memenuhi persyaratan Standar JIS A 5908-2015 hanya kerapatan dan kadar air.

\section{DAFTAR PUSTAKA}

Hadi. 2008. Sifat fisis mekanis papan partikel. Skripsi. Fakultas Kehutanan, Institut Pertanian Bogor.

Haygreen JG, Bowyer JL. 1996. Hasil Hutan dan Ilmu Kayu. Suatu Pengantar. Hardikusumo SA, penerjemah; Prawirohatmodjo S, editor. Yogyakarta: Gajah Mada University Press. Terjemahan dari: Forest Product and Wood Science, An Introduction.

Japanese Industrial Standar. 2015. Japanese Standard Association Particleboard Japan: JIS; (JIS A 5908).

Maloney TM. 1993. Modern Particleboard and Dry Process Fiberboard Manufacturing. San Francisco: MILLER Freemann, Inc.
Saputra YF. 2004. Pengaruh Perlakuan Pendahuluan Partikel dan Kadar Perekat Terhadap Sifat Papan Partikel Tandan Kosong Kelapa Sawit. Skripsi. Bogor: Fakultas Teknologi Pertanian, Institut Pertanian Bogor.

Skinner JD, Jamie RB, Hague, Andrew R. 1999. An Overview of Some Key Issues in The Utilisation of Wheat Straw in MDF. Di dalam: Use of Agricultural Fibers In The Manufacture of Composite Panels. Proceedings of Symposium Meeting on The Forest Product Society; Winnipeg, Manitoba, 19-20 Mei 1999. United States of America: Forest Product Society (47-54).

Sutigno P. 2000. Perekat dan Perekatan. Bogor: Pusat Penelitian dan Pengembangan Teknologi Hasil Hutan.

Trisyulianti E. 1996. Sifat Fisik Mekanik Papan partikel dari Tandan Kosong dan sabut Kelapa Sawit. Skripsi. Bogor: Fakultas Teknologi Pertanian, Institut Pertanian Bogor. 